\title{
Redesain Fasilitas Tangga Sebagai Evaluasi Ergonomi dengan Kerangka Ideas dan Analisis Posture Evaluation Index pada Objek Wisata Muria Kudus
}

\author{
Heru Prastawa ${ }^{1}$, Manik Mahachandra ${ }^{2}$, Ratna Purwaningsih ${ }^{3}$, Eko Satriyo \\ Departemen Teknik Industri, Fakultas Teknik, Universitas Diponegoro \\ Jl. Prof. H. Soedarto, SH, Tembalang, Semarang 50275 \\ ${ }^{1}$ Email: heruprastawa@ft.undip.ac.id \\ ${ }^{2}$ Email: manik.mahachandra@ft.undip.ac.id \\ ${ }^{3}$ Email: ratna.purwaningsih@ft.undip.ac.id
}

\begin{abstract}
ABSTRAK
Tangga, sebagai bagian bangunan yang menghubungkan antar ruangan, sebenarnya sudah dilengkapi dengan standar SNI dalam panduan perancangannya. Namun dalam aplikasinya, masih ada rancangan tangga yang kurang ergonomis dan menimbulkan potensi bahaya, seperti pada lokasi objek wisata Muria Kudus. Jalur pendakian ini memiliki kurang lebih 400 anak tangga, dengan jarak sekitar satu kilometer. Studi ini dilakukan sebagai upaya evaluasi ergonomi pada kondisi tersebut. Berdasarkan hasil kuesioner pendahuluan yang disebarkan pada 30 orang wisatawan dan analisis Posture Evaluation Index (PEI), diketahui bahwa rancangan tangga menyebabkan wisatawan mengalami tekanan berlebih pada otot skeletal yang meliputi punggung, pinggang, dan otot-otot bagian bawah. Penelitian kemudian dilanjutkan dengan simulasi dan Task Analysis Toolkit (TAT) pada Virtual Environment postur aktual dengan perangkat lunak Jack 8.2. Lalu diaplikasikan empat macam konfigurasi desain tangga usulan dengan kombinasi ketinggian pegangan tangan dan ketinggian anak tangga, sesuai SNI 03-1746-2000. Berdasarkan perhitungan ulang nilai PEI dan analisis TAT pada kondisi perbaikan disimpulkan bahwa konfigurasi 10-96 merupakan yang terbaik. Dengan mengaplikasikan solusi praktis ini, maka potensi cedera otot-rangka pada wisatawan yang berkunjung di objek wisata Muria Kudus dapat diminalisir.
\end{abstract}

Kata kunci: Evaluasi ergonomi, Tangga, Posture Evaluation Index (PEI), Task Analysis Toolkit (TAT)

\begin{abstract}
As part of the building that connects between rooms, the staircase design is actually equipped with SNI 03-1746-2000 standard. But in its application, there are stairs that are less ergonomic and pose potential hazards, such as the stairs at Muria Kudus tourism site. The hiking trail has approximately 400 steps and a distance of about one kilometer. This study was conducted as an ergonomics evaluation to this condition. Based on the preliminary questionnaire results to 30 tourists and the analysis of Posture Evaluation Index (PEI), it was known that the stair design caused tourists to experience excessive pressure on the skeletal muscles which include the back, waist and lower muscles. The study then continued with simulation and Task Analysis Toolkit (TAT) on the actual Virtual Environment posture using the 8.2 Jack software. Four types of configuration formulation were proposed to improve hand grip height and stair height, according to the SNI 03-1746-2000. Based on the recalculation of the PEI value and the TAT analysis in the proposed posture, we concluded that the 10-96 configuration was the best. By applying this practical solution in the future, the potential hazard of injury for tourists visiting the Muria Kudus sure can be minimized.
\end{abstract}

Keywords: Ergonomics evaluation, Staircase, Posture Evaluation Index (PEI), Task Analysis Toolkit (TAT) 


\section{Pendahuluan}

Pada sebagian besar wilayah Indonesia, sektor pariwisata merupakan sektor unggulan daerah yang memegang peranan penting dalam pembangunan perekonomian daerah dan nasional. Tingginya angka wisatawan lokal maupun mancanegara memberikan kemakmuran bagi penduduk setempat dan juga negara. Atas dasar ini, pemerintah daerah kian berlomba menciptakan objek wisata unggulan daerahnya masing-masing, yang tak hanya menarik, namun juga nyaman untuk dikunjungi. Tak ketinggalan tentunya, objek wisata alam yang sampai saat ini tinggi peminatnya.

Kabupaten Kudus, sebagai kabupaten dengan luas wilayah terkecil di Jawa Tengah - dengan luas $42.516 \mathrm{Ha}$ atau hanya 1,31 persen dari luas Provinsi Jawa Tengah - memiliki potensi besar di bidang pariwisata. Daerah ini memiliki beberapa objek wisata alam yang strategis dan potensial untuk dikelola, dikembangkan, dan dipasarkan. Salah satu dari sekian objek wisata tersebut adalah komplek wisata Muria Kudus. Komplek wisata yang terletak di wilayah utara kota Kudus ini semakin ramai dikunjungi wisatawan dari tahun ke tahun, karena memiliki beberapa objek wisata alam seperti air terjun Monthel dan telaga warna Rejenu, serta objek wisata religi makam Sunan Muria Kudus.

Tidak dapat dipungkiri bahwa salah satu hal yang menunjang keberhasilan suatu objek wisata adalah sarana dan prasarana yang terdapat di dalamnya. Objek wisata dengan prasarana yang nyaman secara tidak langsung akan memberi dampak positif pada peningkatan kunjungan wisatawan, demikian pula sebaliknya. Salah satu prasarana tersebut adalah tangga, yaitu bagian dari bangunan, yang menghubungkan satu lokasi dengan lokasi lainnya. Berdasarkan observasi awal, tangga yang terdapat pada kompleks wisata Muria Kudus belum memenuhi Standar Nasional Indonesia, yang terlihat dari desain dan spesifikasi tangga tersebut. Selain itu, rancangan tangga dinilai kurang memperhatikan aspek kenyamanan dan keamanan, karena tidak memiliki komponen rel pegangan tangan dan rest area.

Studi pendahuluan kemudian dilakukan dengan menyebarkan kuesioner kepada 30 orang wisatawan. Responden awal ini dipilih secara acak, dengan syarat usia lebih dari 17 tahun. Berdasarkan hasil studi pendahuluan, diketahui bahwa:

1. Wisatawan mengalami keluhan pada otot skeletal, yang meliputi punggung, pinggang, dan otot-otot bagian bawah

2. Tidak tersedianya fasilitas penunjang jalur evakuasi, toilet, rest area

3. Rendahnya aspek kebersihan
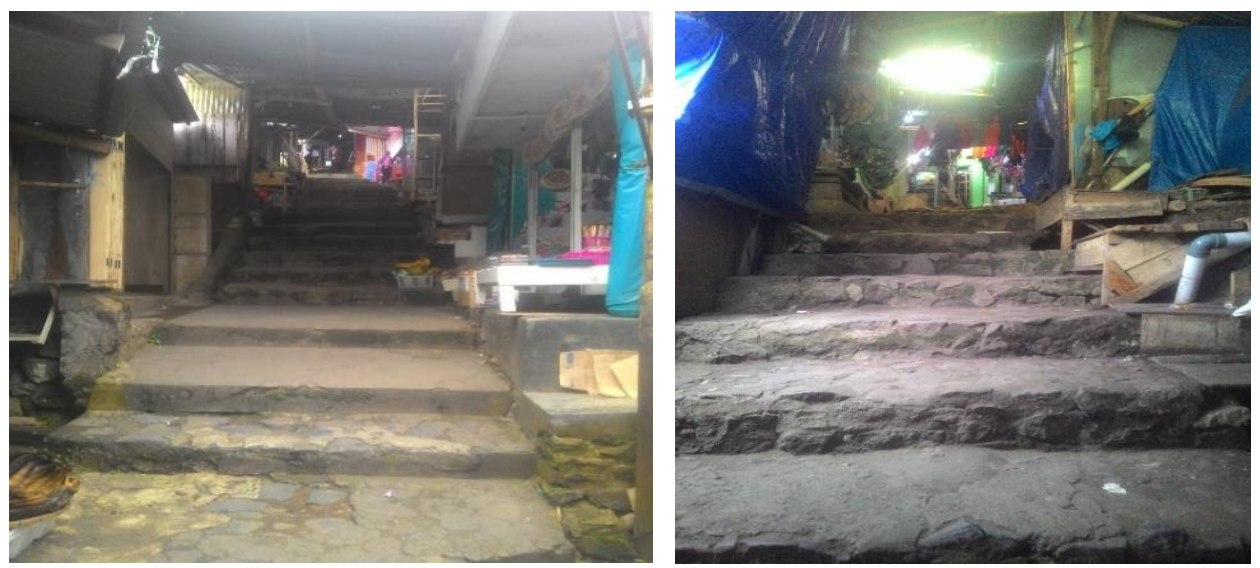

Gambar 1. Jalur tangga pada kondisi aktual

Pada Gambar 1 terlihat bahwa desain tangga yang ada masih kurang memperhatikan keamanan. Diantaranya karena tidak adanya rel pegangan tangan, jarak antar tangga yang terlalu lebar, serta jarak antar anak tangga yang terlalu tinggi. Berdasarkan wawancara dengan pihak pengelola dan wisatawan terdapat beberapa kejadian kecelakaan seperti terpeleset dan keseleo yang terjadi pada jalur tangga tersebut. Beberapa wisatawan menyampaikan bahwa mereka mengalami tekanan pada otot skeletal, yaitu meliputi punggung, pinggang, dan otot-otot bagian bawah. Hal ini umumnya terjadi akibat dari ketidakcocokan desain dengan postur tubuh pengguna.

Mengacu pada Bridger [1], intervensi ergonomi dapat diberikan pada kondisi tangga tersebut, yaitu dengan "mendesain ke dalam" sebuah antar muka (interface) yang lebih baik atau dengan "mendesain ke luar" faktorfaktor yang ada di lingkungan (environment), kegiatan kerja (task), atau organisasi (organization). Rancangan fasilitas tangga yang dilakukan sebaiknya mengacu pada desain antropometri pengguna, yang didasarkan pada 
dimensi tubuh tertentu yang kemudian dapat menghasilkan rancangan yang nyaman bagi sebagian besar penggunanya, sebagaimana disampaikan oleh Wignjosoebroto [2] dan Sutalaksana et al. [3].

Berdasarkan latar belakang masalah tersebut, pada penelitian ini dilakukan perancangan ulang desain tangga dengan pendekatan antropometri yang juga disesuaikan dengan ketentuan pada SNI 03-1746-2000. Metode IDEAS diterapkan sebagai konsep perancangan desain, dan perangkat Jack 8.2 digunakan dalam perhitungan dan perancangan tangga dan postur tubuh, dengan memperhitungkan nilai Posture Evaluation Index (PEI) saat menaiki jalur tangga. Dengan langkah tersebut, maka penelitian diharapkan dapat memberikan perbaikan yang menyeluruh dalam perancangan tangga guna meningkatkan kenyamanan pengunjung.

\section{Metode Penelitian}

Kerangka kerja identify-design-evaluate-adapt-sustain (IDEAS) [4] diterapkan dalam penelitian ini untuk mencapai tujuan yang telah ditetapkan. Mulai dari tahap identify, dilibatkan 30 orang wisatawan di objek wisata Muria Kudus yang dipilih secara acak sebagai responden. Data yang diambil meliputi tinggi badan, berat badan, postur tubuh saat menaiki tangga, dimensi tangga, serta kondisi lingkungan di sekitar tangga dalam bentuk foto dan video.

Pada tahap design, perangkat lunak Jack 8.2 digunakan untuk mensimulasikan postur tubuh manusia [5] dengan memasukkan data antropometri hasil pengukuran. Selain itu, juga dimanfaatkan perangkat lunak AutoCAD untuk mensimulasikan dimensi tangga. Selanjutnya pada tahap evauate dilakukan perhitungan Posture Evaluation Index (PEI), yang didalamnya meliputi analisis Static Strength Prediction (SSP), Low Back Analysis (LBA), OVAKO Working Posture Analysis System (OWAS), dan Rapid Upper Limb Assessment (RULA).

SSP digunakan untuk mengetahui apakah kegiatan yang disimulasikan memungkinkan untuk dilakukan oleh sebagian besar populasi orang. Jika output nilai SSP kurang dari 95\%, maka analisis tidak bisa dilanjutkan karena kegiatan tersebut dinilai dalam kategori yang tidak bisa dilakukan sebagian besar populasi orang. Perhitungan LBA, di sisi lain, dilakukan untuk mengetahui besarnya tekanan kompresi yang dialami bagian tulang belakang. Selanjutnya, OWAS dilakukan untuk mengetahui apakah postur dikategorikan nyaman bagi keseluruhan anggota tubuh. Kemudian, RULA digunakan untuk menilai risiko otot-rangka postur tubuh secara lebih detil pada bagian atas tubuh. Keempat analisis tersebut merupakan bagian dari Task Analysis Toolkit (TAT) pada perangkat lunak Jack 8.2.

Pada dua tahap akhir, yaitu adapt dan sustain, dilakukan redesain tangga dengan mempertimbangkan empat macam konfigurasi ukuran rancangan tangga berdasarkan SNI 03-1746-2000 [6], seperti yang ditunjukkan pada Gambar 2. Konfigurasi ini disusun dari kombinasi dimensi tinggi anak tangga dan tinggi pegangan tangan, yaitu 10-86, 10-96, 18-86, dan 18-96. Nilai PEI kemudian dihitung kembali dan dibandingkan dengan kondisi saat ini. Terakhir, dipilih satu konfigurasi rancangan dengan nilai PEI terkecil yang menunjukkan risiko otot-rangka terendah, atau dengan kata lain memberikan tingkat kenyamanan terbaik bagi penggunanya.

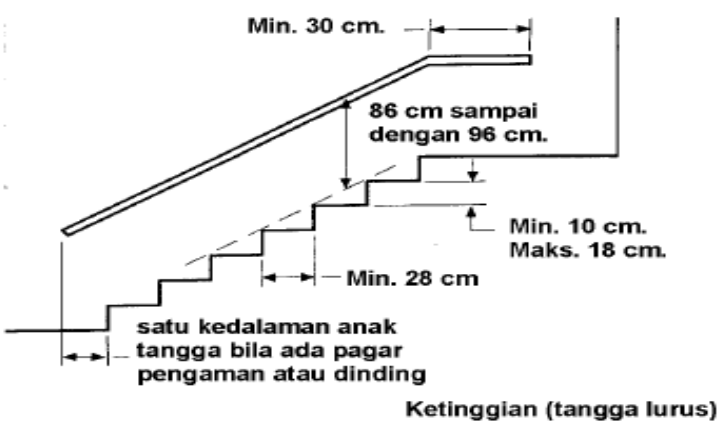

Gambar 2. Standar SNI 03-1746-2000 untuk rancangan tangga

\section{Hasil dan Pembahasan}

\subsection{Pengumpulan Data}

Data yang dikumpulkan meliputi dimensi tangga, postur tubuh saat menaiki tangga, tinggi badan, dan berat badan. Data antropometri yang digunakan pada perangkat lunak Jack 8.2 kemudian adalah antropometri Asian_Indian_NID97 [7], yang dipilih karena mendekati sebagian besar data Antropometri orang Indonesia. Penilaian postur kerja dilakukan pada model pria dan wanita sesuai kondisi di lapangan. 


\subsection{Perancangan Model Aktual}

Langkah berikutnya adalah menyusun virtual environment sesuai dengan kondisi aktual yang diperoleh dari perekaman data foto dan video, seperti yang ditunjukkan dalam Gambar 3. Virtual environment adalah representasi dari sistem fisik yang dihasilkan oleh komputer, yaitu suatu representasi yang memungkinkan penggunanya untuk berinteraksi dengan lingkungan sintesis sesuai dengan keadaan lingkungan nyata [8]. Kemudian dilakukan pula pembuatan virtual human, sesuai dengan postur tubuh yang diamati, yang ditampilkan pada Gambar 4.

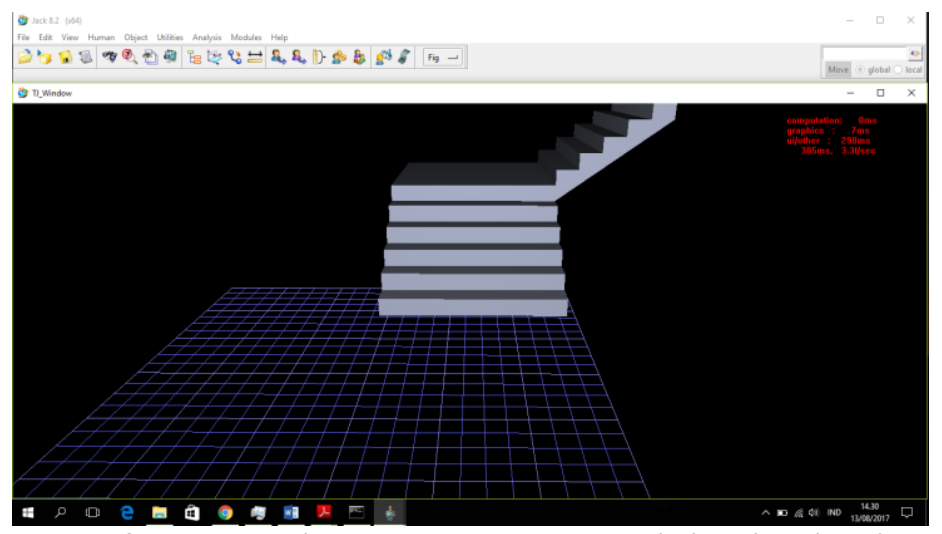

Gambar 3. Virtual environment tangga pada kondisi aktual

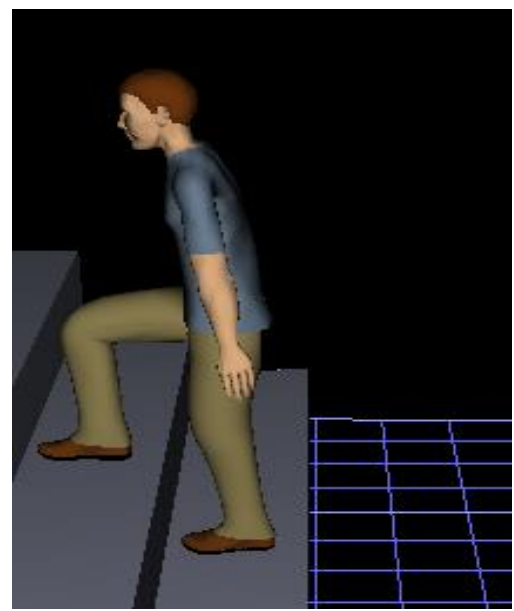

Gambar 4. Postur tubuh pada kondisi aktual

Selanjutnya dijalankan analisis TAT pada perangkat Jack 8.2, yaitu berupa perhitungan SSP, LBA, OWAS, dan RULA, untuk kemudian dihitung secara keseluruhan sebagai nilai PEI. Tabel 1 menunjukkan hasil analisis PEI untuk masing-masing jenis kelamin.

Tabel 1. Hasil analisis TAT pada kondisi aktual

\begin{tabular}{ccccc}
\hline Kelamin & LBA & OWAS & RULA & PEI \\
\hline Pria & 551 & 2 & 3 & $\mathbf{1 , 2 6}$ \\
Wanita & 469 & 2 & 3 & $\mathbf{1 , 2 3}$ \\
\hline
\end{tabular}

\subsection{Perancangan Model Perbaikan}

Pada tahap rancangan model perbaikan ini diterapkan empat macam konfigurasi tangga berdasarkan SNI 031746-2000, yang disusun dari kombinasi tinggi anak tangga dan tinggi pegangan tangan sebesar 10-86, 10-96, 18-86, dan 18-96. Gambar 5 dan Gambar 6 secara berturut-turut menunjukkan kondisi tangga dan postur tubuh pada model usulan. 


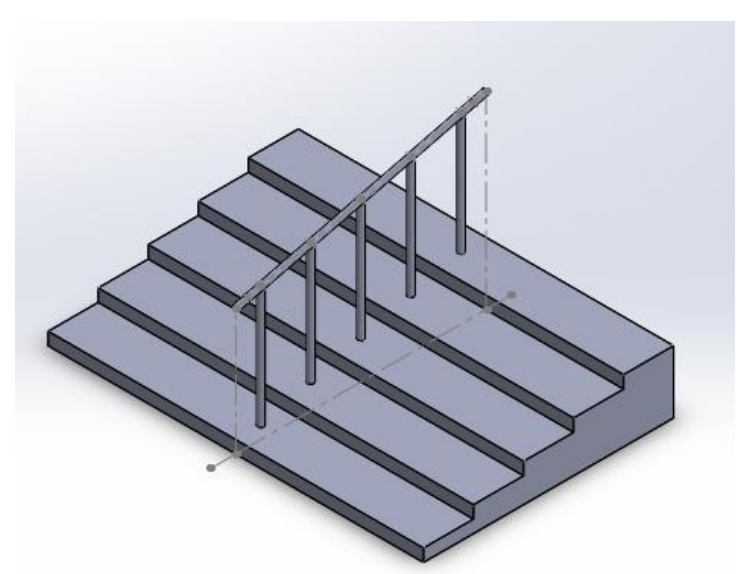

Gambar 5. Virtual environment tangga pada kondisi perbaikan

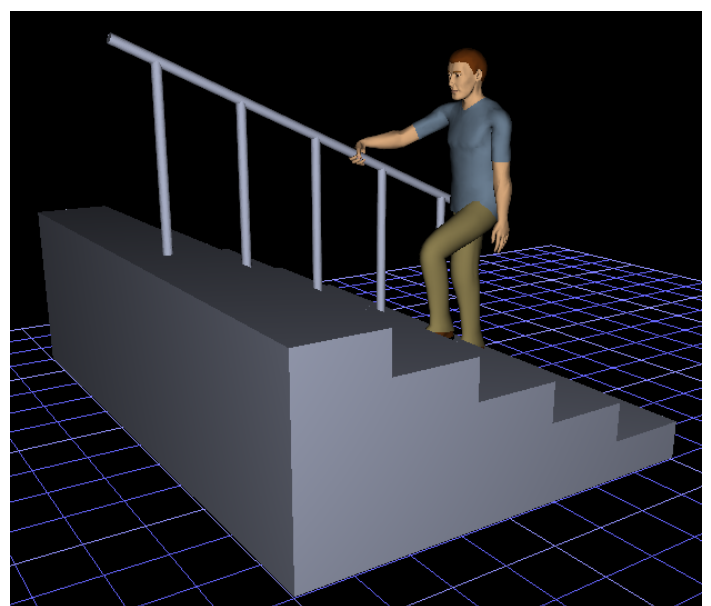

Gambar 6. Postur tubuh pada kondisi perbaikan

Selanjutnya kembali dijalankan analisis TAT dari hasil perhitungan SSP, LBA, OWAS, dan RULA pada postur tubuh pada model perbaikan untuk masing-masing konfigurasi rancangan tangga. Nilainya kemudian dianalisis lebih lanjut sehingga menghasilkan nilai PEI, masing-masing untuk jenis kelamin pria dan wanita seperti yang telah dirangkum dalam Tabel 2.

Tabel 2. Hasil analisis TAT pada kondisi perbaikan

\begin{tabular}{llllll}
\hline Desain Perbaikan & Kelamin & LBA & OWAS & RULA & PEI \\
\hline \multirow{2}{*}{ Konfigurasi 10-86 } & Pria & 575 & 1 & 3 & $\mathbf{1 , 0 1}$ \\
\cline { 2 - 6 } & Wanita & 439 & 1 & 3 & $\mathbf{0 , 9 7}$ \\
\hline \multirow{2}{*}{ Konfigurasi 10-96 } & Pria & 580 & 1 & 3 & $\mathbf{1 , 0 2}$ \\
\cline { 2 - 6 } & Wanita & 364 & 1 & 3 & $\mathbf{0 , 9 5}$ \\
\hline \multirow{2}{*}{ Konfigurasi 18-86 } & Pria & 502 & 1 & 3 & $\mathbf{1 , 0 1}$ \\
\cline { 2 - 6 } & Wanita & 365 & 1 & 3 & $\mathbf{0 , 9 6}$ \\
\hline \multirow{2}{*}{ Konfigurasi 18-96 } & Pria & 514 & 1 & 3 & $\mathbf{1 , 0 1}$ \\
\cline { 2 - 6 } & Wanita & 417 & 1 & 3 & $\mathbf{0 , 9 8}$ \\
\hline
\end{tabular}




\subsection{Perbandingan Model Aktual dan Perbaikan}

Pada tahap terakhir, dilakukan perbandingan hasil perhitungan nilai PEI dalam analisis TAT pada kondisi aktual dan perbaikan untuk masing-masing konfigurasi rancangan tangga. Gambar 7 menunjukkan hasil perbandingan kedua kondisi, baik pada responden pria maupun wanita.

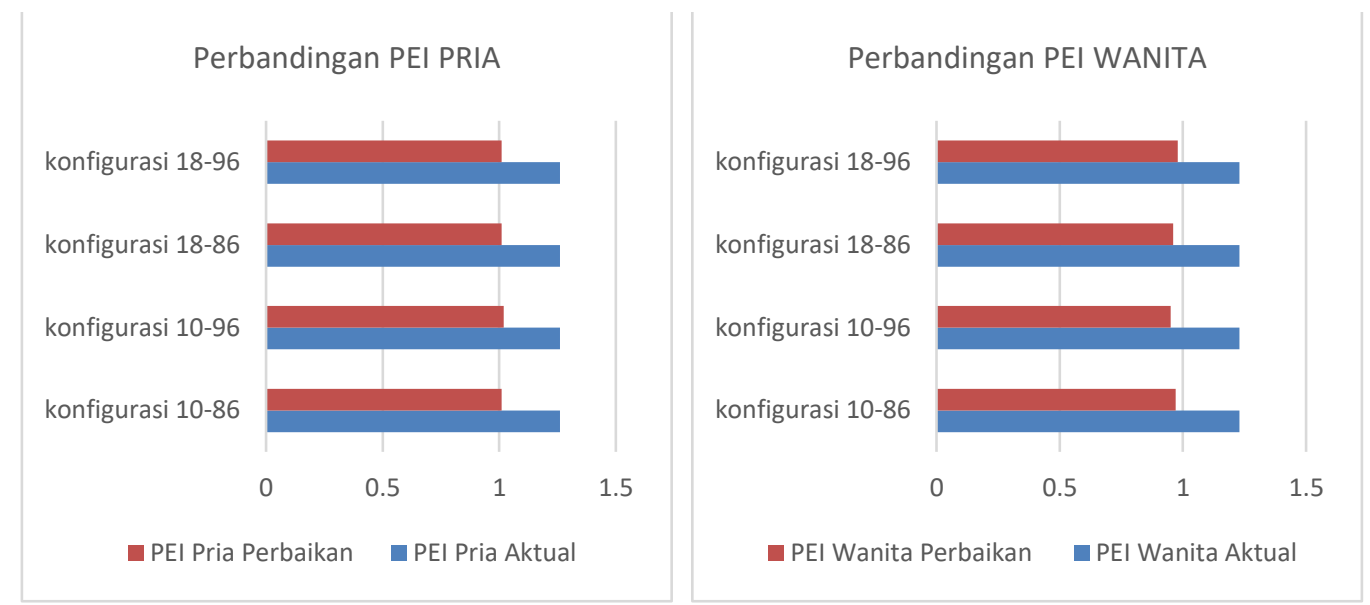

Gambar 7. Hasil perbandingan kondisi aktual dan perbaikan pada pria dan wanita

Hasil perbandingan nilai PEI pada pria memperlihatkan bahwa desain perbaikan sudah berhasil menurunkan nilai risiko cedara otot-rangka pada pria, yang awalnya 1,26 menjadi sekitar 1 . Seperti yang ditunjukkan pada Tabel 2, tiga konfigurasi rancangan tangga menghasilkan nilai PEI sebesar 1,01, dan hanya pada konfigurasi 1096 saja nilai PEI yang dihasilkan sedikit lebih besar, yaitu 1,02. Nilai PEI pada model perbaikan yang lebih kecil mengindikasikan bahwa konfigurasi rancangan tangga hasil redesain berhasil mengubah postur tubuh wisatawan menjadi lebih nyaman saat menggunakan tangga tersebut.

Sejalan dengan hasil perbaikan untuk jenis kelamin pria, desain tangga pada model perbaikan juga berhasil menurunkan nilai PEI wanita dari semula 1,23 menjadi dibawah 1. Diantara keempat rancangan desain konfigurasi perbaikan tersebut, nilai PEI terkecil ditemukan pada konfigurasi 10-96, yaitu dengan nilai 0,95. Nilai PEI pada model perbaikan yang lebih kecil dari pada desain aktual mengindikasikan bahwa konfigurasi perbaikan sudah berhasil mengubah postur tubuh responden menjadi lebih nyaman.

Baik pada responden pria maupun wanita, ternyata model perbaikan yang diusulkan mampu mengubah postur tubuh saat menggunakan tangga menjadi lebih baik, yang terlihat dari penurunan nilai PEI. Berdasarkan kategori penilaian PEI pada Tabel 3, terlihat bahwa desain konfigurasi perbaikan pada kedua kelompok responden tersebut berhasil menurunkan risiko cedera otot-rangka (musculoskeletal injury) dari tingkat middlelow injury menjadi low injury. Dengan berkurangnya risiko cedara ini, maka kenyamanan wisatawan saat menggunakan tangga pun dapat ditingkatkan.

Tabel 3. Kategori PEI

\begin{tabular}{cl}
\hline Nilai PEI & Tingkat Injury \\
\hline 0 & Tidak kritis \\
1 & Low injury \\
2 & Middle-low injury \\
3 & Middle-high injury \\
4 & High injury \\
\hline
\end{tabular}

Selanjutnya, berdasarkan nilai PEI yang dihasilkan pada model perbaikan pria dan wanita, dapat ditarik kesimpulan bahwa alternatif rancangan tangga dengan kombinasi 10-96 memberikan penurunan PEI terbesar, yaitu dengan rerata penurunan sebesar 0,26 untuk kedua jenis kelamin. Dengan demikian, alternatif ini dapat dinyatakan sebagai rancangan terbaik yang dihasilkan pada penelitian ini. Rancangan tersebut tersusun dari konfigurasi ketinggian anak tangga sebesar $10 \mathrm{~cm}$ dan ketinggian pegangan tangan sebesar $96 \mathrm{~cm}$. Dengan mengaplikasikan usulan redesain tangga ini, maka diharapkan keluhan otot-rangka dan potensi cedera yang dapat dialami para wisatawan dapat berkurang secara signifikan. 


\section{Kesimpulan}

Analisis postur tubuh dan rancangan tangga pada kondisi aktual yang dilakukan dengan perangkat lunak Jack 8.2 memperlihatkan kondisi yang berpotensi menimbulkan risiko cedara otot-rangka dalam tingkat middle-low injury. Kondisi aktual ini ditunjukkan oleh nilai Posture Evaluation Index (PEI) sebesar 1,26 dan 1,23, masingmasing untuk pria dan wanita. Rancangan ulang tangga yang kemudian dilakukan dengan mempertimbangkan empat konfigurasi tinggi anak tangga dan tinggi pegangan tangga pada SNI 03-1746-2000 menghasilkan kondisi perbaikan yang sesuai harapan. Nilai PEI pada model perbaikan mengalami penurunan yang cukup signifikan, yaitu menjadi 1,01-1,02 untuk pria dan 0,95-0,98 untuk wanita. Kondisi ini mengindikasikan bahwa hasil redesain tangga mampu mengubah postur tubuh wisatawan, sehingga dapat menurunkan tingkat risiko menjadi low injury, serta meningkatkan kenyamanan wisatawan selama menggunakan fasilitas tangga tersebut.

\section{Daftar Pustaka}

[1] Bridger, R. (2003). Introduction to Ergonomics, Edisi ke-2. New York: Taylor \& Francis.

[2] Wignjosoebroto, S. (2003). Ergonomi Studi Gerak dan Waktu. Jakarta: Guna Widya.

[3] Sutalaksana, I.Z., Anggawisastra, R., \& Tjakraatmadja, J.H., 2012. Teknik Perancangan Sistem Kerja, Edisi ke-2. Bandung: Penerbit ITB.

[4] Tegar (2013). Digital Human Modelling (DHM) to Improve Human Performance and Reduce Musculoskeletal Disorder (MSD) Risk. Jakarta: Ergonomic Centre.

[5] Blanchonette, P. (2010). Jack Human Modelling Tool: A Review. Australian: Air Operations Division.

[6] SNI. (2000). Tata Cara Perencanaan dan Pemasangan Sarana Jalan Ke Luar Untuk Penyelamatan Terhadap Bahaya Kebakaran Pada Bangunan Gedung. Jakarta.

[7] Adam, F. (2015). Evaluasi Postur Kerja yang Ergonomis Pada Operator Jahit Dalam Virtual Environment. Tugas Akhir (tidak dipublikasikan). Semarang: Universitas Diponegoro.

[8] Kalawsky, R. S. (1993). The Science of Virtual Reality and Virtual Environments. Cambridge: AddisonWesley Publishing Company. 